\title{
Emissions calibration yesterday, today and tomorrow
}

\begin{abstract}
The ever increasing complexity in engine control systems and diagnostics functionality, which are vital to meet current and future emissions legislation, presents the industry with the problem of increased programme development and labour costs. As the degree of subsystem complexity intensifies, so too does the requirement for anticipatory driving behaviour knowledge; thereby introducing predictive operating strategies into drivetrain management systems. For example, it is possible to improve the accuracy of gear pre-selection calibrations in dual clutch transmissions by including GPS and gradient sensor data as input parameters; thus improving the off-cycle fuel efficiency of the vehicle. Similarly, benefits can be found by avoiding frequent changes in the combustion engine's operating point or taking the engine's cold start behaviour into account, as well as the effectiveness of the exhaust after-treatment systems, etc. The calibration of conventional powertrain systems are often only solvable with significant effort and the calibration of hybrid management systems are becoming just as complex. Therefore, a future that will require a deeper integration of more complex technologies without the support of structured methodologies, the trade-offs for $\mathrm{CO}_{2}$ and other regulated emissions, performance, comfort, cost and effort cannot be efficiently found. This paper intends to present a standardised approach with which the immense effort in the measurement and simulation of these variables is significantly supported by methods of statistical based test planning, model generation and optimisation, which can be implemented across a wide variety of increasingly flexible development environments. A vision is presented of how the methodologies and tools that are being used today can be adapted in the future to enable engineers to continue to deliver industrialised calibrations that meet the growing legal requirements and fulfil customers' expectations.
\end{abstract}

Key words: automated calibration, calibration methodology, standardisation of processe, hybrid, ECU, TCU, DSG

\section{Kalibracja emisji wezoraj, dziś i jutro}

Nieustanny wzrost złożoności konstrukcji systemów sterowania silnikiem oraz stopień skomplikowania funkcji diagnostycznych niezbędnych do zaspokojenia bieżacych oraz przyszłych wymagań dotyczacych ograniczania emisji szkodliwych składników spalin wymagają od przemystu motoryzacyjnego zwiększenia nakładów na programy rozwoju, a także zwiększenia kosztów pracy. Narastająca złożoność podsystemów wymaga wprowadzenia elementów i uktadów wyprzedzających reakcje kierowcy, wprowadzając tym samym predykcyjne strategie zarzadzania systemami układów napędowych. Na przykład, możliwe jest poprawienie dokładności wyboru biegów przez kalibrację podwójnego sprzęła skrzyni biegów za pomoca GPS i gradientów danych z czujników, jako parametrów wejściowych, co przyczyni się do obniżenia poziomu zużycia paliwa przez pojazd. Podobne korzyści moga być uzyskane dzięki unikaniu częstych zmian warunków pracy silnika, a także optymalizacji pracy silnika podczas zimnego rozruchu, co również poprawi skuteczność katalitycznych uktadów oczyszczania spalin.

Kalibracja konwencjonalnych układów napędowych jest często możliwa do przeprowadzenia tylko przy znacznym nakładzie pracy, a kalibracja systemów zarzadzania napędem hybrydowym jest jeszcze bardziej skomplikowanym procesem. Należy się spodziewać się, że już w niedalekiej przyszłości konieczne będzie stosowanie bardzo złożonych zintegrowanych technologii, wspierajacych zmniejszanie zużycia paliwa, a także ograniczajacych emisję dwutlenku węgla $\left(\mathrm{CO}_{2}\right)$ i innych szkodliwych sktadników spalin oraz poprawiajacych osiagi, komfort jazdy i obniżajacych koszty eksploatacji pojazdu.

$W$ artykule przedstawiono standardowe podejście, w którym szeroki zakres niezbędnych badań empirycznych i symulacyjnych może być wspierany statystycznymi metodami planowania badań i optymalizacji, które moga być implementowane w różnych elastycznych środowiskach programowych. Zaprezentowano także, w jaki sposób powinny być doskonalone obecnie stosowane metody i narzędzia, aby zapewnić w przyszłości dostępność narzędzi kalibracyjnych, spetniających rosnace wymagania prawne i oczekiwania użytkowników.

Słowa kluczowe: automatyczna kalibracja, metodologia kalibracji, kalibracja emisyjna, standaryzacja, napęd hybrydowy, ECU, TCU, DSG

\section{Introduction}

One of the major challenges for the automotive industry today is to condense product development times whilst maintaining quality. A reduction in the duration to get a new product to market enhances the company's overall flexibility to respond to changes in the marketplace.

A recent case where external factors forced unexpected change in the engine calibration community was the sudden increase in oil prices combined with the financial crisis in late 2008. Within a matter of weeks, automakers witnessed the sales of their larger, less efficient vehicles drop to historic lows. It was clear that manufacturers would need to improve the fuel efficiency of their entire fleet in order to retain their share of the market. By mid-2009, most major automotive manufacturers in Europe were offering 'stop-start' functionality in at least some of their vehicles. Whilst it is probable 
that many of these manufacturers had planned to introduce the 'stop-start' control functionality in the near term, it was the rapid rollout of this complex control strategy that helped them to reduce their certified fuel consumption figures by as much as $15 \%$ 'overnight,' thereby quenching the market's initial thirst for more efficient vehicles.

The traditional approach to reducing product development times has been to substitute experimentation and testing of components or systems with simulation. Over the last 15 years there has been significant progress in the development and application of simulation tools, but due to the complexity of modern vehicles, it is not possible to completely replace experimentation and testing with simulation. In some cases work steps that were previously conducted in the testbed environment are moving back to road based testing. A combined approach is needed.

Furthermore, engines are required to operate in environmental extremes such as the harsh winters of northern Finland and the high ambient temperatures of Death Valley, California. For engines that use forced induction, the trade-off between performance and component protection in high altitudes creates a significant workload for calibration engineers. Simulation of these environmental conditions requires access to wind tunnels and climatic chambers combined with robust optimisation strategies for the thermal management systems; however this particular subject will not be the focus of this paper.

Most calibration engineers will tell you that the most stressful part of a project occurs during the months leading up to the calibration freeze date. Commonly it is because the robustness and maturity of the initial hardware supplied to the calibration team does not permit the creation of calibration datasets that can be used in the final production vehicle. During the earlier phases of a project it is equally common to find that engineers have very little workload predominantly due to the lack of suitable testing equipment.

Therefore, a process that can make use of this initial 'slack' time in calibration projects to provide useful data with minimal quantities of hardware is the key to reducing the overall project time. This process is known as 'front loading' the project and is the main focus of this paper.

\section{The past}

Up until the mid 20th century, the design ethos for internal combustion engine manufacturers was focused on improving the efficiency and power density of their products. However, in the booming post war economy of America, the environmental impacts from the widespread usage of I.C. engines were beginning to be noticed by legislators. By the late 1950's the United States government had introduced the first emissions legislation for vehicles, with many western governments closely following suit.

However, during the subsequent two decades the emissions regulations were still comparitively relaxed and due to the limited technological capabilities of the time, more stringent legislative requirements would have proved difficult to meet.

The calibration process during this era was based on hardware adjustments. Basic measurements of temperatures, pressures and rotational speeds were predominantly conducted in-vehicle. There was no on-board diagnostics capability or thermal management and ultimately, driveability was a product of the initial hardware selection.

Degradation of components over the vehicles lifetime would often demand "re-calibration" in a workshop.

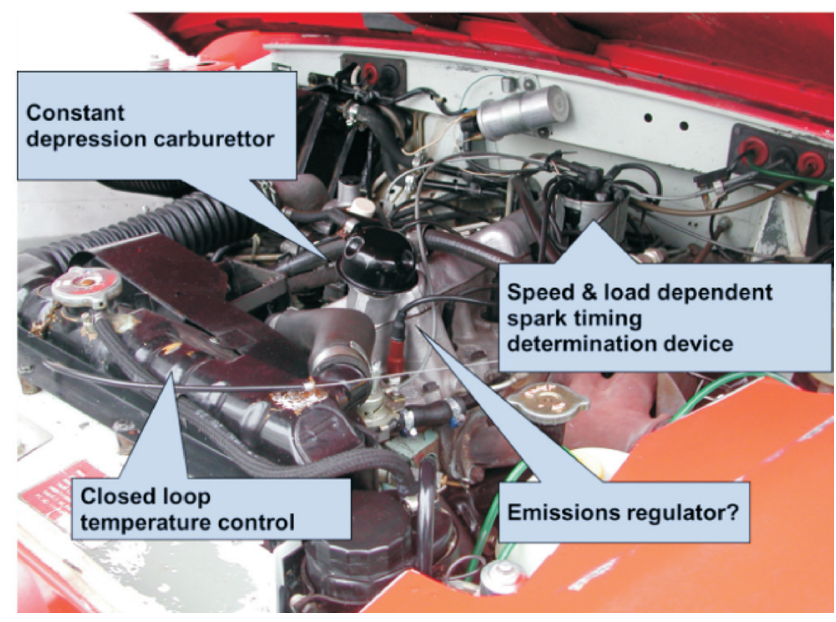

Fig. 1. Under the hood of a Land Rover from the late 1960's

\section{The present}

The legislative requirements to lower exhaust emissions and improve OBD functionality have been the driving force in engine development over the last 30 years. The implementation of electronic control systems has been the main technology enabler.

Other customer driven requirements such as efficiency, quality, driveability, power density, etc. have an important role to play in the powertrain development process and contribute strongly towards brand identity. Hence, whilst these demands often conflict with one another, they cannot be discounted during the development process.

The key benefits of using electronic control system can be characterised by the following features:

- Full 'online' ECU access

- Adaptive control functions

- Sophisticated driveability functions

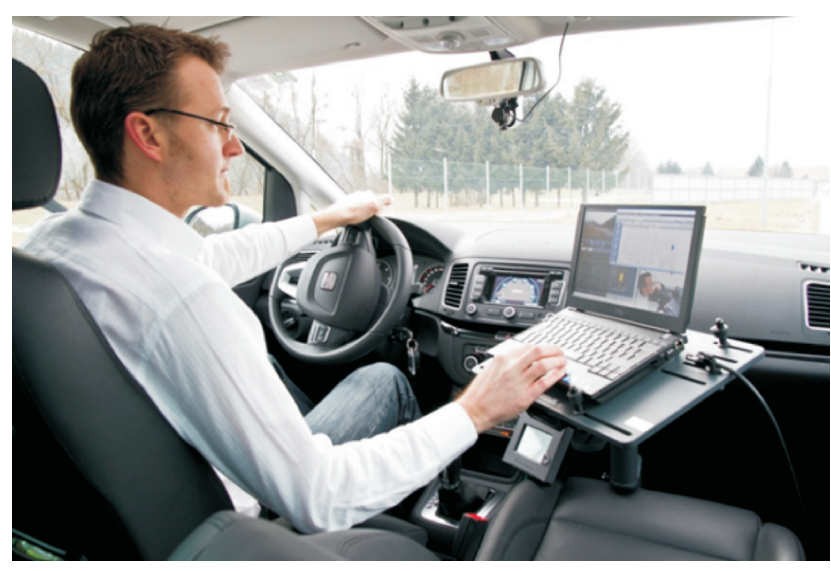

Fig. 2. Approximately $35 \%$ of calibration tasks are performed in vehicle today 
- OBD ( $>50 \%$ of all functions)

- Ability to calibrate for specific emissions drive cycles (as required by legislation)

- Access to additional measurements in vehicle (ECU, CAN, temperatures and pressures, GPS, etc.)

- Ability to monitor degradation of vehicle components over lifetime

- Where necessary, it is possible to release software updates through dealer networks.

The complete engine calibration process can be split into the following four subtasks:

- Base engine and component protection

- Emissions and exhaust gas after treatment

- On-board diagnostics

- Driveability.

If we take a passenger car that meets the current (Euro V) emissions legislation as a contemporary example; we can examine the most common methodology and proc- behaviour of automatic transmissions and vice versa. With the proliferation of electrification technologies, there are now further management systems integrated in the drivetrain. Apart from the battery and electric motor controllers, there are now also HCUs (Hybrid Control Unit), which determine the operating strategy in various driving situations. It is worth mentioning here, that complete vehicle control units have been implemented in heavy duty vehicles for many years. For example, modern tractors adapt their control strategy according to the status of the individual and aggregate load situations.

The explosion in the number of control units increases the necessity to network the control units together. This results in massive cross-dependencies of individual functions, or labels, which up until recently were only able to be dealt with separately and independently.

For example, the ability to power a vehicle with $100 \%$ electrical power cannot be simply assessed via the state of

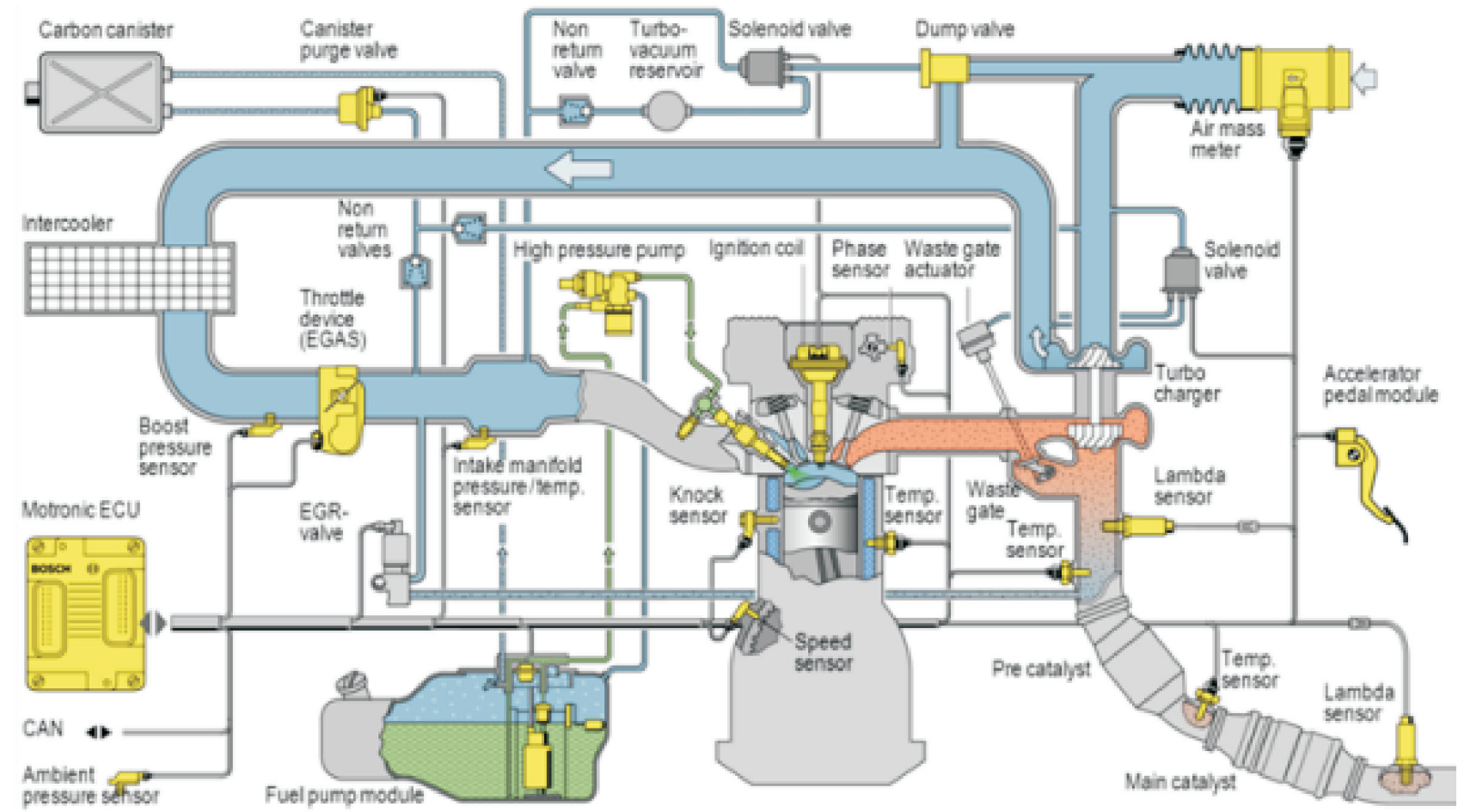

Fig. 3. The basic calibration components in a modern day automobile

esses used by engineers to optimise the aforementioned tasks.

\subsection{Data management}

For many years, the development processes for combustion engines and transmissions could be largely regarded as being independent of one another. The only points of contact in the total vehicle development process were the milestones for the delivery into the complete drivetrain.

In the mid-nineties, the introduction of the torque-based combustion engine control uncovered the cross-dependencies between ECU and TCU. If changes were made in the engine management system this had a knock-on effect on the shift

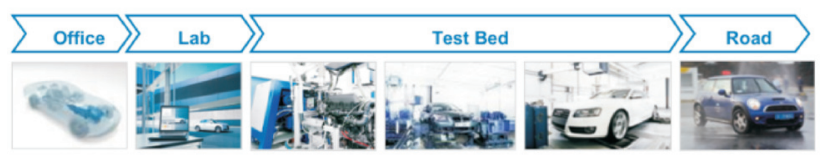

approx. $35 \%$ of calibration tasks are in-vehicle

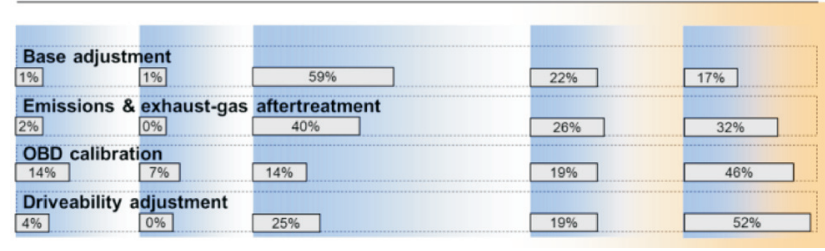

Fig. 4. Task split with breakdown of test environments 
battery charge; but also by taking into account a possibly too low catalytic converter temperature, which would make the continuing use of the combustion engine necessary. The idle control and pull-away behaviour can also be controlled differently depending on the state of battery charge. Diagnostic functions in particular need to consider the aforementioned cross dependencies, because the emissions results depend heavily on the operating strategy selected. Finally, the operating strategy will need to be changed or adapted if a fault is detected and diagnosed.

In order to be able to react to these situations, it will be necessary to identify all cross-dependencies on a functional and label level, and to be able to guarantee that all project participants are at least aware of them.

A simple reactive behaviour by a data management system will, however, not be sufficient. At the very beginning of a project, all critical functions and labels should be uniquely identified and allocated to the calibrator who has responsibility for them. By doing this method, iterative loops in the development process and inaccurate calibration can be minimised or at best avoided at the beginning of a project.

Consequently, it is necessary to store all data sets from the various control units in a central database and to clearly allocate access rights to the individual project participants. A centralised and component-oriented data-

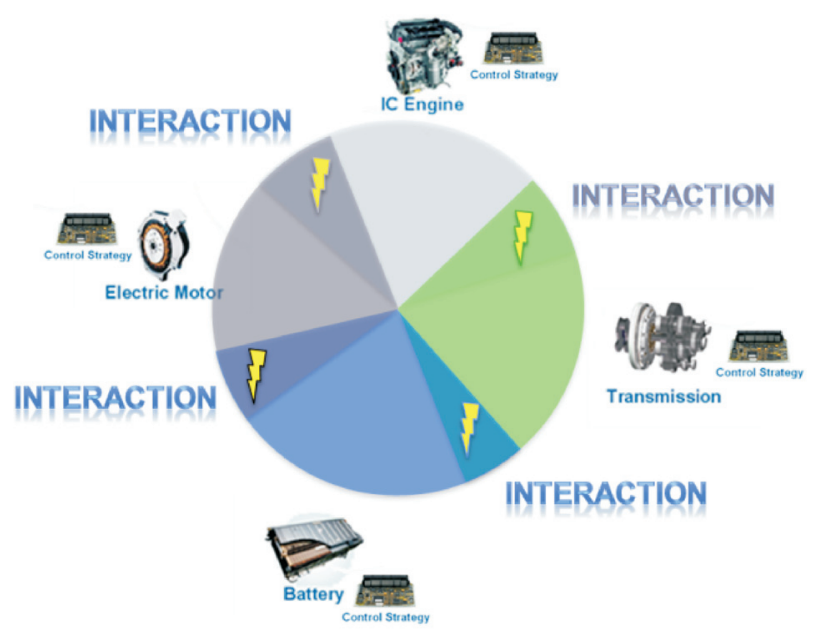

Fig. 5. Increased complexity and a high degree of co-dependency between subsystems is becoming the norm

base can also be called upon in future projects for purposes of pre-calibration. In order to increase the effectiveness of this solution, information concerning the source of the data sets should also be stored alongside information concerning the test plan used, the test strategy implemented and which modelling and optimization algorithm was used. If available, specific workflows and standards can also be stored alongside the data sets. When using model-based approaches, it is also important to store and reference any ECU models and plant models that were implemented [1].

\subsection{Automated engine optimisation}

Automated running of engine test beds has been around for some time and the introduction of this feature does not inevitably result in more efficient resource usage or shorter development times. Sometimes this has been referred to as "just enabling engineers to burn more fuel." Hence, the data produced during automated test runs must be relevant to the project and of a high quality.

The conventional methodology takes an iterative approach, whereby an engineer will prepare a test case and run the experiments on the engine. Once the data has been produced, the engineer must take the time to carefully analyse the results and prepare a new test case before running the second iteration of the experiment, and so on, until a satisfactory dataset is produced or enough empirical data is collected to create an adequate model offline.

With simple adjustments to base engine calibrations, this iterative approach can be quite effective and fast. However, more commonly, the increased flexibility in modern engines means that this logical approach becomes incredibly time consuming and complex when dealing with multiple inter-reliant variables. An example of this would be a modern common rail diesel engine whereby the performance in the emissions region is a function of the following parameters:

- Boost pressure set-point and pre-control

- EGR set-point and pre-control

- Fuel rail pressure

- Pilot injection timing and separation

- Pilot injection fuel quantity

- Main injection timing and quantity

- Post injection timing and quantity

- Intercooler bypass and throttle set-point.

The interaction between these variables means that it can be very difficult to find a coherent calibration strategy.

A problem whereby design criteria are to be optimised for several target functions simultaneously depending on

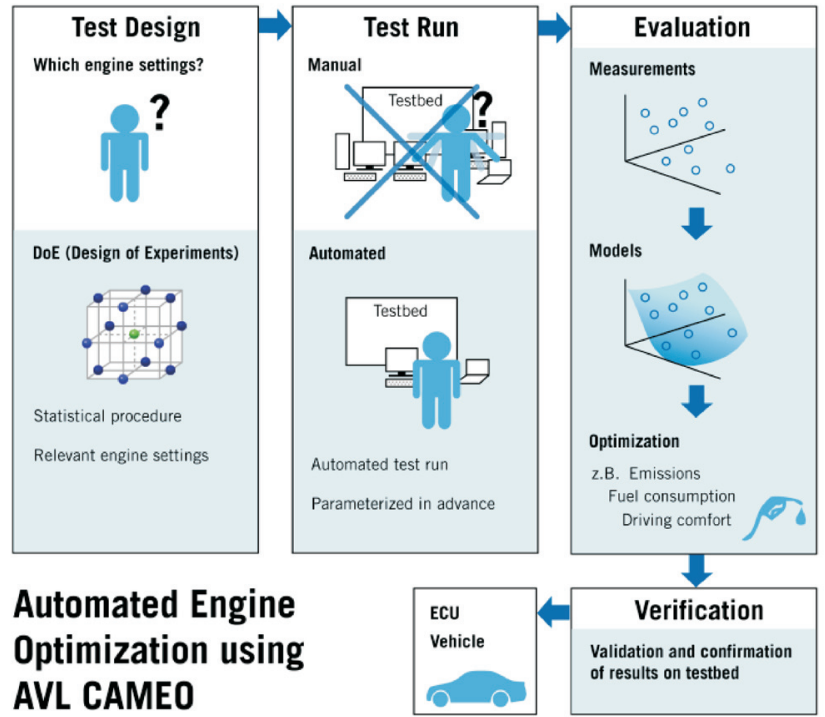

Fig. 6. The engine calibration process using AVL CAMEO 
multiple constraints is called a multi-objective problem (MOP). If the target functions are in conflict with each other, then it is difficult to optimise all target functions simultaneously. Hence it is necessary to introduce the concept of "non-dominating individuals," as long as there is no valid solution within the design space.

Usually, a multi-objective problem does not have a single such solution but a set of solutions, which can be described as a Pareto front [2].

Modern DoE software enables one to dramatically reduce the number of iterative steps taken when developing an emissions or base engine calibration using the 'Adaptive Online' DoE method. This is done by pre-screening the design space for operating points that lie within the specified

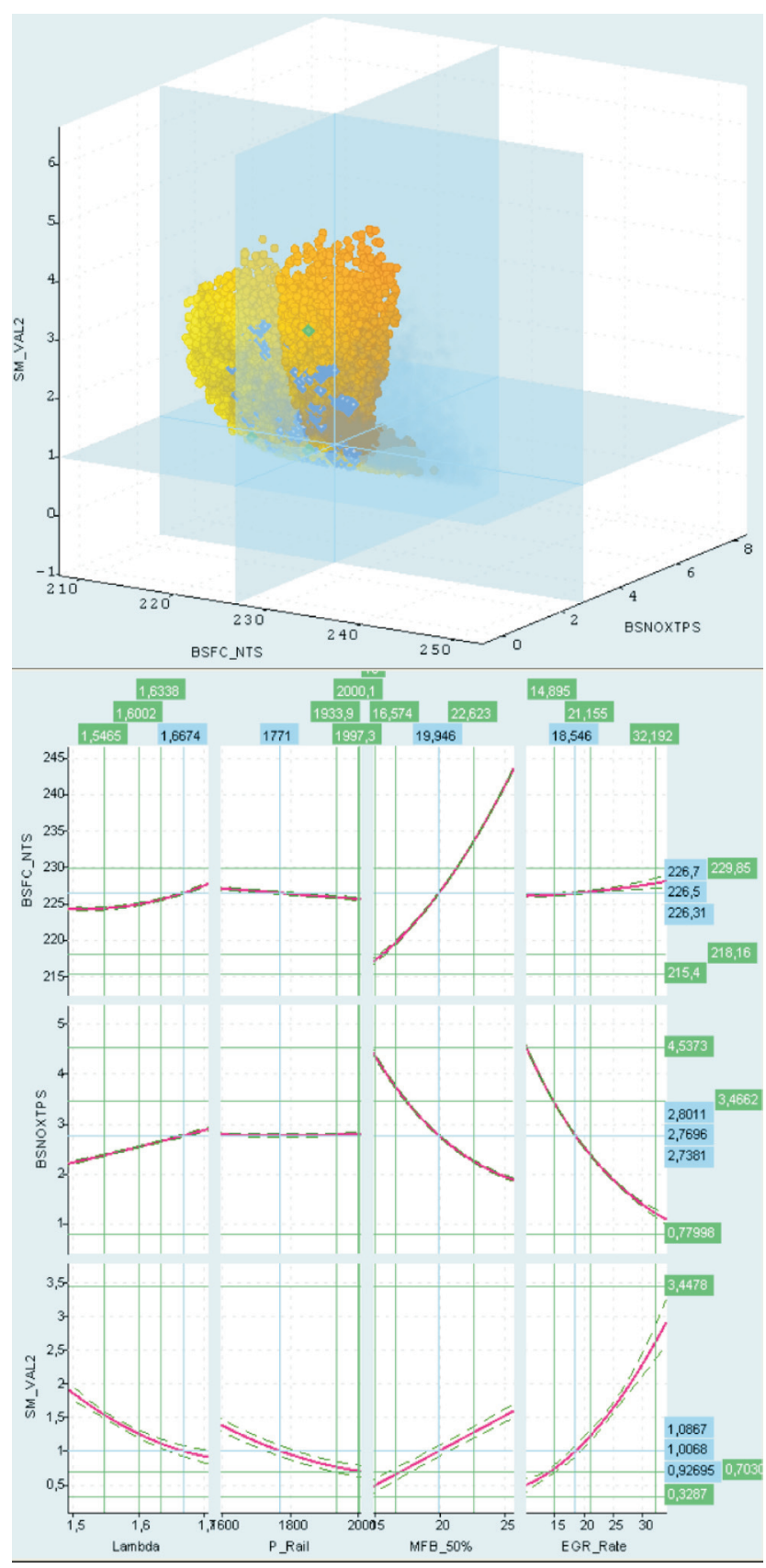

Fig. 7. Fast verification of the optimal points through interaction with the intersection graphic and Pareto front graphics design criteria. By eliminating 'bad zones' from the design space, it can reduce the amount of 'junk' data generated during the automated test.

Once a design space has been screened and adjusted, the DOE software will proceed to start the test run. Once any statistical outliers have been eliminated, the generated data can be used to build models of the interacting variables. These models give the user the ability to quickly verify the measured operating points and search for an optimal strategy though examination of the Pareto front and intersection plots, see Fig. 7.

Through the skilled application of DoE tools and intelligent testing strategies, it is possible to reduce the time spent on the engine testbed by as much as $50 \%$. The additional benefit of being able to run the testbed 24 hours a day with minimal supervision, whilst ensuring safe and stable operation, further enhances these savings.

\subsection{Simulated emissions drive cycles}

A fundamental element needed to further reduce development times via frontloading of projects is to simulate the emissions drive cycle in the engine test bed. Unlike the heavy duty industry, this process will never be used for the final emissions certification and homologation of the passenger vehicle. It is, with the correct preparation, possible to simulate an emissions drive cycle on high dynamic dynamometers and achieve repeatable emissions results that

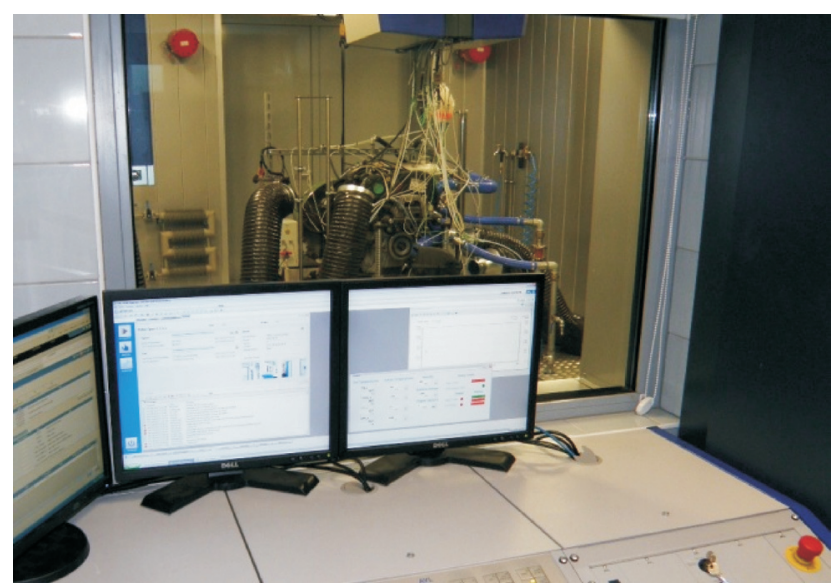

Fig. 8. One of the recently updated CAMEO testbeds at BOSMAL

are directly comparable with chassis dyno tests using a robot driver and test vehicle.

The contemporary method of using test vehicles in the chassis dyno suffers from the following major drawbacks:

- Driver repeatability - often resolved by using robot drivers.

- Maturity of test vehicles - during the early stages of the projects, key components such as the final drive gear may not have been selected, or they are simply not available to use in the tests.

- Robustness of early prototype vehicles: These are often hand built vehicles and it is quite difficult to provide vehicles in adequate numbers that are comparable in terms of 
hardware. Mechanical failure rates are often much higher during these earlier phases of development.

- 12 hour soak times are needed to allow the vehicle and transmission to cool down to reach the nominal environmental criteria before starting the test.

- High cost associated with producing fleets of early prototypes for chassis dyno tests.

Using the simulated emissions drive cycles on the testbed has the following benefits:

- Testing can start as soon as the engine hardware selection has been made and a stable coast down curve has been provided.

- Quick turnaround between emission cycle tests: By fast cooling the engine, it is normal to be able to produce approximately six emission drive cycles during an 8 hour shift.

- The simulations can cover different vehicle variants, automatic or manual transmissions and can assist in the selection of gear ratios.

- Depending on the maturity of the base engine calibration and engine hardware, it is possible to have a very high level of robustness and repeatability during this early testing phase, thereby enabling an emissions calibration freeze during the first few half of a development project.

With the increased focus on BSFC during the emissions development phase, it is common to hear the phrase; "every 10th of a gram of $\mathrm{CO}_{2}$ counts on this project." Therefore, it is increasingly necessary to carefully specify the shift schedule on automatic transmissions in combination with the emission calibration strategy, which can result in multiple iterative loops. Previously, it was possible to freeze the shift schedule very early on in the project because it was usually defined by the desired driveability characteristics. The need for a precise level of test repeatability is evident when searching for incremental reductions $\mathrm{CO}_{2}$ and ultimately excludes the usage of human drivers during the early parts of the emissions drive cycle development phase. Human drivers are obviously still needed for the validation phase to prove the robustness of the emissions calibration prior to certification.

In Figure 9, a quick analysis was made during a recent calibration project to understand where the bulk of the increased fuel consumption was arising from on a dual clutch transmission (DSG) variant. In this specific case the difference between the two variants was less than $2 \mathrm{~g} / \mathrm{km}$ of $\mathrm{CO}_{2}$. By running two emissions drive cycles on the engine test bench with the same emissions calibration, one with a DSG transmission model and the other with a manual transmission model and comparing the results, it was immediately obvious that the engineering team needed to re-focus on improving the efficiency during the low speed phase of the drive cycle.

The answer to this question was provided in a few hours using the simulated drive cycle approach on an engine testbed. To make the same comparison using a single physical engine on a vehicle chassis testbed would have been prohibitively expensive and time consuming.

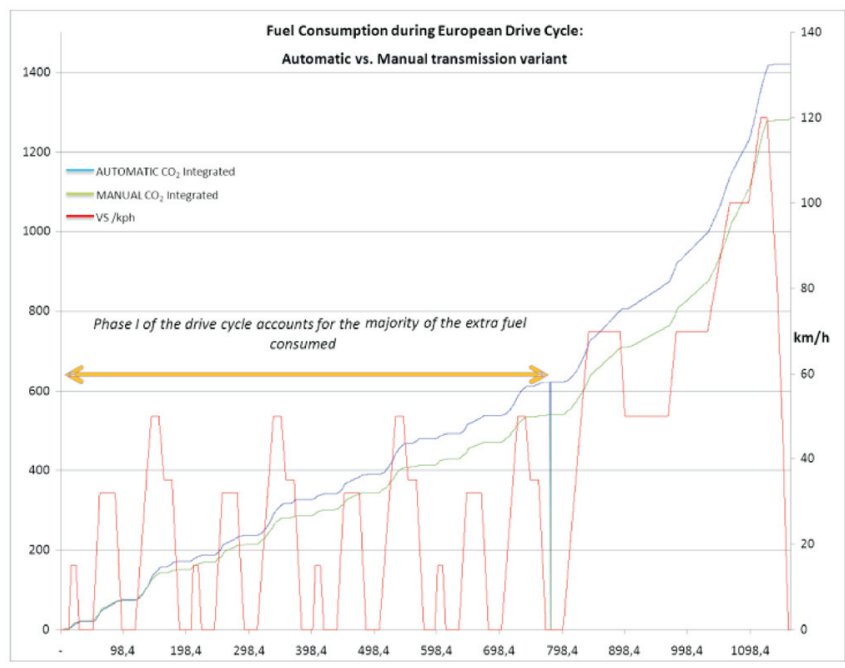

Fig. 9. Quick comparison made of two transmission variants using data from simulated emissions cycles in an engine test bed

\subsection{Post-processing and function development within the calibration process}

It is possible to pre-calibrate individual parts of the software functionality in the control unit in the office by using models of the various components of the drivetrain.

The operating strategy of ECUs are based upon multiple sources of information concerning the state of the vehicle, the ancillary system requirements, the transmission, the road conditions and the current torque requirements demanded by the driver.

Many characteristic parameters of these systems are not directly measurable in production vehicles because of the prohibitive price of the sensors, or their physical size and thus these values need to be derived either from observer or approximation based functions in the corresponding control units. These functions can be pre-calibrated in the office through the use of simulation and optimisation of measurement data gained from the drivetrain testbed, component test bench or from an instrumented vehicle. Common examples are clutch models, temperature models of various components, load state models for the batteries as well as 'look-up tables' that estimate the emissions for the exhaust after-treatment systems.

By transferring such calibration tasks into the office, it is possible to considerably reduce the time, effort and costs associated with these tasks. The complete system can now be analysed and calibrated based upon these replacement virtual or empirically derived models. An important feature of such simulation chains is also the analysis and development of operating strategies, which can be simply exchanged and compared with each other.

\subsection{Importance of development environments}

Today, as a whole, calibration engineers spend the majority of their time working in-vehicle. As previously discussed some of the workload is transferring into simulated environments, but most automakers require extensive verification work to be conducted in extreme environments.

A simple case whereby workload can be transferred into the engine test bed environment from the road early on the 
development project (where test objects may not be available) is the initial driveability studies. For example, it is possible to start the calibration of the pedal maps on a high dynamic test bench by conducting simulated in-gear accelerations as described in Figure 11. The response characteristics of the air-path system and ultimately torque response can be measured with a degree of accuracy and repeatability that is difficult to achieve in-vehicle. Comparisons can be made between different drive-train solutions, such as gear ratios or wheel radius in combination with multiple simulated vehicle variants and infinite engine calibrations.

Combining this test methodology for driveability studies on the engine testbed with the aforementioned DoE packages and driveability rating systems further enhances one's capability to cover a wider scope of parameterisation and deliver finely tuned calibrations at a very early phase in the project.

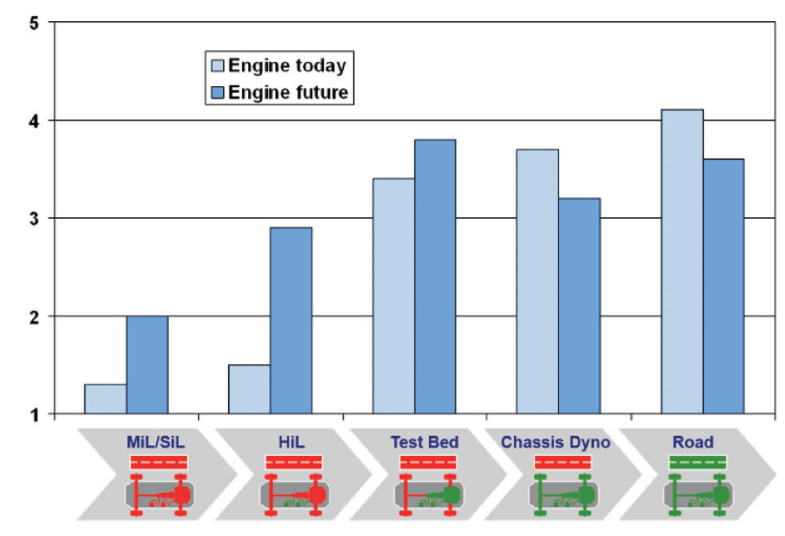

Fig. 10. The progression from road to laboratory

\section{The future}

\subsection{Standardisation of processes}

The calibration workflow can usually be divided into three main steps - independently of the calibration task and the drivetrain under consideration. In order to be able to efficiently execute these work steps; tools and methods that have a strong vertical consistency are required. This means that, depending on the task, there must be a chain of tools that integrate closely in order to provide the calibrator with the best possible support.

At the same time, there exists the requirement to be able to use the same tools on the same class of work steps; in order to reduce the number of different tools engineers must employ (horizontal equality).

\subsection{Calibration of transient modes}

As emissions regulations become more stringent in terms of total mass and permitted excursions above legislated values; then the original focus by the industry on controlling 'quasi' steady state emissions no longer holds true for all circumstances.

Feed-forward control algorithms are continuously being developed to limit the impact that heavy transients through combustion modes and operating points can have on the integrated emission results. However, these forward control algorithms have a reputation for being notoriously difficult to calibrate, in part due to the requirement for a high degree of model accuracy and the necessity for these algorithms to adapt to the spread in hardware tolerances derived from production variance changes over vehicle lifetime.

Thus, with further proliferation of these model based transient control algorithms, the industry will need more powerful tools to aid in their calibration.

\subsection{Flexibility of development environments}

A clear pattern has emerged in the industry where we can observe a migration from the road to the testbed and simulation environments, and this is expected to continue in the future.

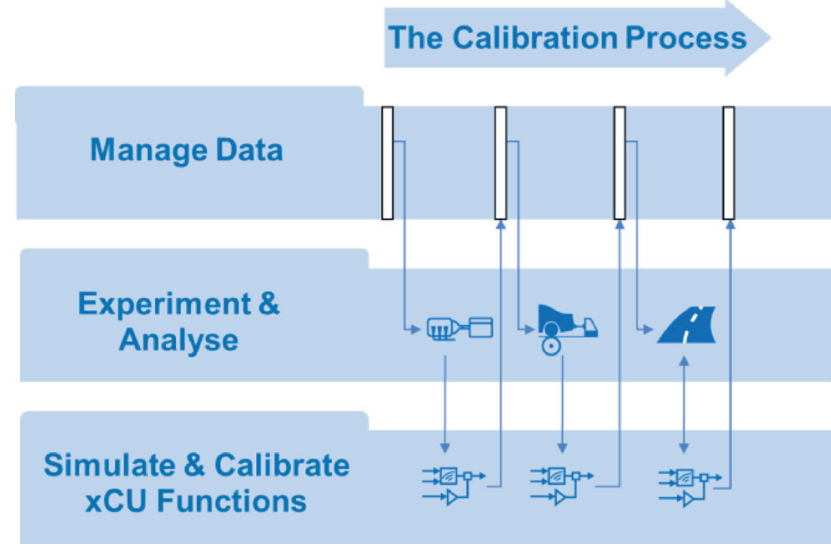

Fig. 12. The three main phases within the calibration process

To further enable successful transfer of work steps to these environments, the industry will need to focus on the following objectives:

- Unified testing throughout the entire development process - Achieve best results for manoeuvre-based testing - Verify and improve the overall quality of simulation.

\subsection{In-vehicle measurement devices}

The next set of emissions legislation sets out the requirement for passenger cars to fulfil the criteria for 'in-use performance ratios'(IUPR). These set boundary limits for regulated emissions that must not be exceeded by the production vehicles during their operating lifetime without setting a diagnostic fault code. For the calibration teams, this translates to a significant amount 


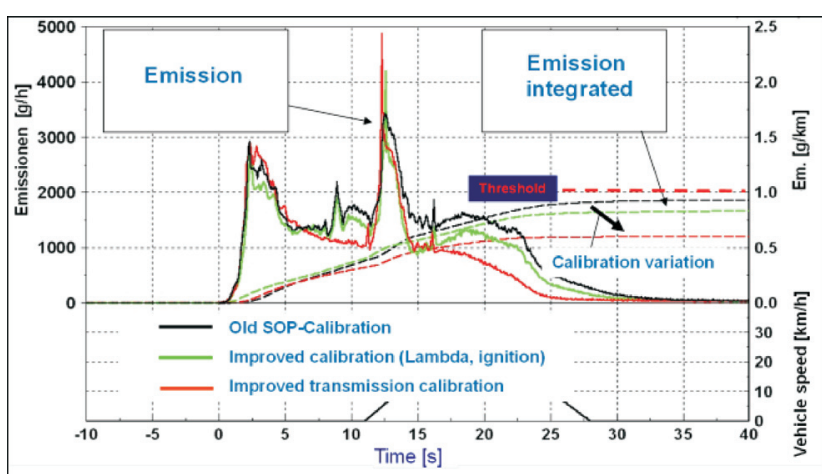

Fig. 13. The result on integrated exhaust emissions through the incremental increase in control over transient emissions excursions

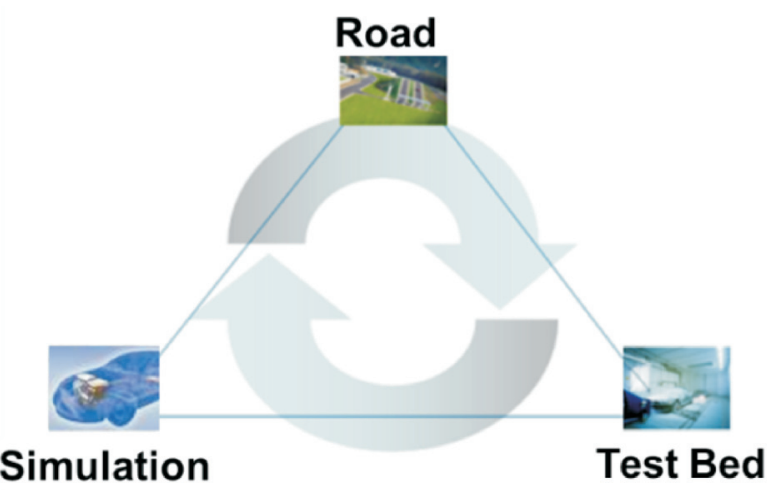

Fig. 14. Information is continuously transferred between the road, the test bed and simulation

of OBD verification work combined with the prerequisite to measure exhaust emissions on the road. These measurement devices must meet the following criteria:

Flexibility

- Open system architecture

- Easy system integration.

Durability and portability

- Ability to withstand severe shock and vibrations

- Operational in extreme environments

- Minimal volume and mass.

Simplified installation \& operation

- Data security

- Minimize required operating span gas

- Fast data acquisition and measurement device re-calibration.

\section{Conclusions}

Over the last century, calibration engineers have often been criticised for not adopting the more scientific methodologies used by their peers in other fields.

Collectively, the calibration community has started to regain this lost ground by developing more coherent strategies and processes. These have enabled it to undertake more efficient, predictable development projects in multidisciplined environments.

History tells us that the volatility of the global crude oil price is something we will have to deal with again in the future. This instability in the energy markets has already demonstrated its' impact on the demand for hybrid electric

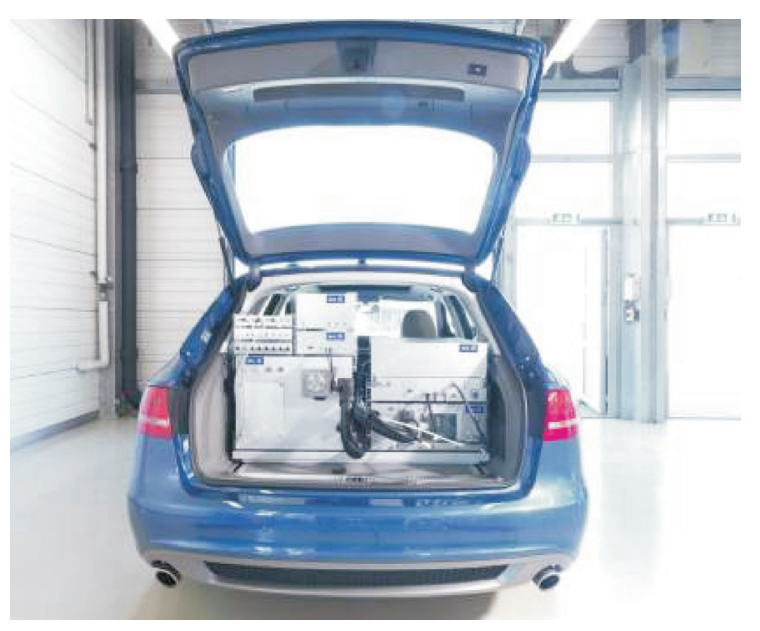

Fig. 15. AVL's solution for in-vehicle emissions measurement systems

vehicles over the last few years, particularly in the US market; thereby defining near term product strategy for automotive companies. Due to the high component and development on-cost of hybrid or plug-in vehicles; these vehicle choices becomes non-viable for around $14 \%$ of consumers when the gasoline price falls by approximately $25 \%$ [3].

The net-effect for calibration departments is that they will be put under increasing pressure to deliver projects with a higher degree of technical complexity in shorter timeframes in order to meet these fluctuating consumer demands.

Paper reviewed/Artykut recenzowany

\section{Bibliography/Literatura}

[1] Zach Ch., Schatz P., Kokalj G., Keuth N., Combé T.: Model based strategy optimisation for hybrid electric vehicles -4 th International Symposium on Development Methodology. Technical University of Darmstadt 2011.

[2] Combé T., Steigerwald K., Hollerer P., Mitterecker H., Vogels M.S., Wimmler Th.: New methods for dynamic emission calibration - 4th International Symposium on Development Methodology. Technical University of Darmstadt 2011.

[3] Beresteanu A., Shanjun L.: gasoline prices, government support, and the demand for hybrid vehicles in the U.S. Department of Economics, Duke University, 2008.

Eike Martini, MEng. - Global Business Segment Manager Calibration Applications at AVL List GmbH, Graz, Austria.

Mgr inż. Eike Martini - kierownik działu klienta globalnego aplikacji kalibracyjnych w AVL List GmbH, Graz, Austria.

e-mail:eike.martini@avl.com

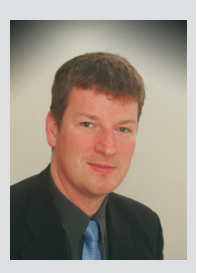

Neil Coghlan, BEng, MPhil. - Calibration leader for a diesel passenger car meeting Euro $\mathrm{V}$ emissions at AVL List GmbH, Graz, Austria.

Mgr inż. Neil Coghlan - Gtówny specjalista ds. kalibracji silników ZS pojazdów klasy emulsyjnej Euro V w AVL List GmbH, Graz, Austria.

e-mail:ncoggy@gmail.com

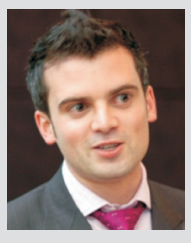

